\title{
Tragedy increases woes of US ice fleet
}

The main US ship for Arctic research is patching together plans for next year's cruises under the shadow of safety concerns, after its marine science officer and a crewman died while diving under the ice.

The US Coast Guard icebreaker Healy is scheduled to begin operations in April, as part of International Polar Year, in which hundreds of scientists from at least 60 countries will launch projects at the poles. But US agencies are experiencing considerable challenges, including replacing two ageing icebreakers, securing a crucial helicopter service, and training icebreaker crews for scientific missions.

And in a telephone conference on 16 November, Coast Guard officers told US research agencies that divers may not be available for the 200 days of scientific operations that the Healy is scheduled to complete. A Navy-certified dive team typically supports researchers aboard the 128-metre icebreaker, helping with equipment and operations in the water.

On 17 August, while stopped in pack ice about 800 kilometres north of Barrow, Alaska, marine science officer Jessica Hill and a mate, Steven Duque, died while on a short dive under the ice. Hill, a marine biologist who was also the ship's dive officer, was conducting a 'familiarization' dive for the less-experienced Duque.

When the divers ran into difficulties, crew members pulled them out of the water via life- line ropes. Resuscitation was unsuccessful and the divers were pronounced dead. The Healy steamed to Alaska, where Coast Guard officials relieved the captain, suspended all dives, and cancelled the ship's two remaining research cruises for 2006. A month-long cruise led by scientists at the University of New Hampshire in Durham, who are mapping the continental shelf to redraw the US economic zone, was delayed until next September. And a cruise to test an under-ice vehicle operated by researchers from Woods Hole Oceanographic Institution in Massachusetts was cancelled. The team will deploy the vehicle next summer without the benefit of a full test run.

"We were disappointed," says Simon Stephenson, director of the Arctic science division of the US National Science Foundation (NSF). "But this was a safety issue; there was concern about the crew functioning properly."

Coast Guard investigations into the deaths are due to be completed by February 2007. Earlier this month, military officials released autopsy reports to the families in Florida. Hill, 30 , died of asphyxiation, with lung trauma from a likely unconscious ascent from about 60 metres down. The report says that both divers' air tanks were empty. "Nothing will bring her back, but I would like to know what happened," says retired microbiologist William Hill, the woman's father.
The tragedy adds to difficulties already being experienced by the US fleet of four icebreakers. In September, the Government Accountability Office reported on the inadequacies of the ageing ships, and a National Academy of Sciences panel called for the replacement of two of them (Polar Sea and Polar Star).

The Healy is the newest of the fleet, commissioned in 2000, and the only one primarily devoted to scientific missions. But there have been difficulties with the Healy's Coast Guard crew having sufficient technical experience to support researchers on board. In recent years, the NSF has had to contract out various services, including the handling of ocean-floor cores (to Oregon State University) and key depth and temperature data (to Scripps Institution of Oceanography). Last summer the agency also had to pay for a contract helicopter service for some cruises, doubling costs to US $\$ 600,000$, because Coast Guard helicopter engines were being replaced.

Stephenson is now aiming for a more coordinated approach. Next year, he says, the NSF will issue a request for proposals in which one institution would provide scientific support personnel for the Healy. The contract, worth around \$1 million, is to be in place for 2008 . But Stephenson is still aiming to fill a monthlong gap in June, when no team is scheduled to use the ship. "It's ironic this is happening [during International Polar Year]," he admits. "But I predict there will be too much demand in 2008."

Rex Dalton

\section{Italian government eases in radical reforms}

The tiny, elegant and undeniably ancient Rita Levi-Montalcini - Nobel laureate and, at 97 , still active in her role as senator-for-life - thrust the plight of Italian research into the headlines last week. She pledged to vote against the new government's 2007 budget if last-minute cutbacks for science were not reversed.

That small battle was won, and the bill passed through the first of the Italian parliament's two chambers on 18 November with a final budget for universities and research only slightly lower than that for this year.

There is still much fighting to be done, but when the stringent 2007 budget - designed to reduce Italy's soaring deficit - is finally signed off in December, scientists are likely to see a significant increase in research project money, a decrease in funding for infrastructure, and a smallerthan-anticipated increase in new positions for young academics.

This may disappoint those who had higher hopes for the avowedly research-friendly centre-left coalition government that took office in the summer. But behind the headlines, more fundamental changes to the research system have quietly taken place. Two key decrees were approved last week, which in the long run may serve the scientific community better than immediate cash injections.

One decree creates an evaluation agency for universities and research, which should be established by the spring. Its first task will be to broadly grade universities on their performance

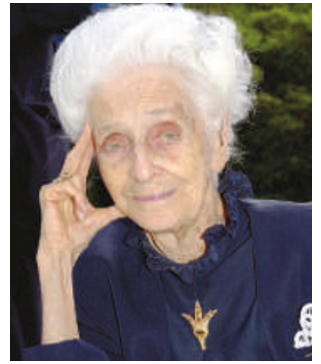

Defending Italian science: Rita Levi-Montalcini in teaching and research, producing three or four groupings that the ministry for universities and research will eventually use to allocate funds. "The agency's aim is to gradually improve, not to judge," says Luciano Modica, the research ministry's undersecretary. Modica hopes the agency will also help to solve other problems 
